\title{
ШЛЯХИ ФУНКЦІОНУВАННЯ СФЕРИ ФІЗИЧНОЇ КУЛЬТУРИ В НОВИХ СОЦІАЛЬНО-ЕКОНОМІЧНИХ УМОВАХ
}

\author{
Максим Ячнюк ${ }^{1}$, Ірина Ячнюк ${ }^{1}$ Юрій Ячнюк ${ }^{1}$ \\ ${ }^{1}$ Чернівецький національний університет імені Ю. Федьковича, Чернівці, Україна. m.yachnyk@chnu.edu.ua
}

https://doi.org/10.29038/2220-7481-2020-02-33-37

\begin{abstract}
Анотації
Актуальність теми дослідження. Перехід України на нові економічні умови, негативно позначився на діяльності багатьох спортивних організацій різних форм власності. У зв'язку з цим постає необхідність пошуку та реалізації нових форм і підходів до організації позанавчальної фізкультуро-оздоровчої та спортивно-масової роботи з різними верствами населення України, які б відповідали соціально-економічним реаліям сьогодення. Аналіз вітчизняної теорії й практики фізичного виховання різних груп населення засвідчує, що рівень залучення громадян до рухової активності в Україні потребує функціонування нової, сучасної системи фізичного виховання - спорту для всіх, що $є$ закономірним результатом пошуку ефективних шляхів забезпечення доступності для населення рухової активності заради зміцнення здоров'я людини. Світовий досвід показує, що створення мережі спортивних клубів є ефективним засобом покращення здоров'я та підвищення рухової активності громадян. Мета дослідження - дослідити шляхи функціонування сфери фізичної культури в сучасних соціально-економічних умовах. Методи дослідження. Для досягнення поставленої мети проведено теоретичний аналіз науково-методичної літератури й документальних матеріалів, системний аналіз досягнень вітчизняних дослідників із цієї проблематики. Результати дослідження. Сучасні українські клуби - невід'ємна складова частина соціально-культурного та спортивного життя країни. Вони представлені як у державному, так і в комерційному секторах культури й характеризуються розгалуженою інфраструктурою, різноманітністю послуг, що надаються громадянам у їхньому бажанні щодо покращення власного здоров'я та використання різних видів рухової активності. Висновки. Поєднання спеціально організованих і самостійних видів оздоровчої рухової активності в діяльності центрів фізичного здоров'я населення $є$ актуальним на цьому етапі розвитку індустрії спорту в нашій державі.
\end{abstract}

Ключові слова: фізична культура, спортивні клуби, фітнес-клуби, здоров’я.

Максим Ячнюк, Ирина Ячнюк, Юрій Ячнюк. Пути функционирования сферы физической культуры в новых социально-экономических условиях. Актуальность темы исследования. Переход Украины на новые экономические условия негативно отразился на деятельности многих спортивных организаций разных форм собственности. В связи с этим возникает необходимость поиска и реализации новых форм и подходов к организации внеучебной физкультурно-оздоровительной и спортивно-массовой работы с разными слоями населения Украины, которые бы отвечали социально-экономическим реалиям сегодняшнего дня. Анализ отечественной теории и практики физического воспитания разных групп населения свидетельствует, что уровень привлечения граждан к двигательной активности в Украине требует функционирования новой, современной системы физического воспитания - спорта для всех, что есть закономерным результатом поиска эффективных путей обеспечения доступности для населения двигательной активности ради укрепления здоровья человека. Мировой опыт показывает, что создание сети спортивных клубов есть эффективным способом улучшения и повышения двигательной активности граждан. Мировой опыт показывает, что создание сети спортивных клубов есть эффективным способом улучшения и повышения двигательной активности граждан. Цель исследования - исследовать пути функционирования сферы физической культуры в современных социально-экономических условиях. Meтоды исследования. Для достижения поставленной цели проведен теоретический анализ научно-методической литературы и документальных материалов, системный анализ достижений отечественных исследователей по данной проблематике. Результаты исследования. Современные украинские клубы есть составляющей частью социально-культурной и спортивной жизни страны, они представлены как в государственных, так и в коммерческих секторах культуры и характеризуются разветвлённой инфраструктурой, разнообразием услуг которые предоставляются гражданам в их желании к улучшению собственного здоровья и использование разных видов двигательной активности. Выводы. Объединение специально-организованных и самостоятельных видов оздоровительной двигательной активности в деятельности центров физического здоровья населения есть актуальным на данном этапе развития индустрии спорта в нашей стране.

Ключевые слова: физическая культура, спортивные клубы, фитнес клубы, здоровье.

Maksym Yachniuk, Iryna Yachniuk, Yuriy Yachniuk. The Ways of Functioning of Physical Culture Sphere in New Socio-Economic Conditions. The Research Topic Relevance. The transition of Ukraine to new economic conditions has negatively affected the activities of many sports organizations of diverse ownership forms. In this regard, it is necessary to seek and implement new forms and approaches to the organization of extracurricular physical culture, 
health-improving and sports mass work with different segments of Ukraine's population, which would correspond to the contemporary socio-economic realities. The analysis of domestic theory and practice of physical education of various population groups indicates that the involvement level of citizens in motor activity in Ukraine requires the functioning of a new, modern system of physical education - sport for everyone, which is a natural result of finding effective ways ensuring accessibility of population physical activity to promote human health strengthening. The world experience has shown that the creation of sports clubs network is an effective way to improve health and increase the motor activity of citizens. The Study Aims to examine the ways of functioning of the physical culture sphere in contemporary socio-economic conditions. The Research Methods. To achieve this aim, the theoretical analysis of scientific and methodological literature and documentary materials, as well as systematic analysis of the achievements of domestic researchers on this issue, have been carried out. The Research Results. Contemporary Ukrainian clubs are an integral component of social, cultural and sport life of the country. They are represented in both state and commercial sectors of culture and are characterized by branched infrastructure and variety of services provided to citizens in their desire for health improvement and use of different types of motor activity. Conclusions. The combination of specially organized and independent types of health-improving motor activity in the work of physical health centres of the population is relevant at the current stage of the sports industry development in our country.

Key words: physical culture, sports clubs, fitness clubs, health.

Вступ. Аналізу діяльності сучасних спортивних клубів в Україні стосується дослідження Е. Бабенко, О. Гриценка, І. Петрової, Н. Самойленко, Е. Тимо, Н. Цибалюк та інших науковців, котрі обгрунтовують ефективність діяльності й можливості вітчизняних клубів у розвитку та задоволенні різноманітних потреб особистості, пропаганді здорового способу життя серед різних верств населення.

М. Дутчак у своїй монографії приділяє значну увагу обгрунтуванню концепції гуманізації процесу залучення населення до рухової активності, структурно-функціональним особливостям формування системи спорту для всіх в Україні, розглядає питання сучасних технологій державного управління спортом для всіх [1].

Мата дослідження - розкрити шляхи функціонування сфери фізичної культури в сучасних соціально-економічних умовах.

Методи дослідження. Для досягнення поставленої мети проведено дослідження, яке засвідчує, що в Україні фітнес-послугами користуються значна кількість населення. Проте їі структурі притаманні великі розбіжності, а саме, значним попитом такі програми користуються в обласних центрах та великих містах, у той час як фітнес-об'єктів майже немає в районах і в маленьких містечках та сільській місцевості. Теоретичний аналіз науково-методичної літератури й документальних матеріалів, системний аналіз досягнень вітчизняних дослідників із цієї проблематики. Проведений теоретичний аналіз науково-методичної літератури та пошук ефективних підходів до розвитку сфери фізичної культури й спорту в нових соціально-економічних умовах дали нам можливість провести теоретичні дослідження шляхів функціонування сфери фізичної культури в Україні.

Результати дослідження. Дослідження звертає увагу на те, що на сучасному етапі розвитку України як європейської держави однією 3 найважливіших проблем є збереження та зміцнення здоров’я громадян [4].

Аналізуючи дані офіційного сайту Міністерства охорони здоров’я України, бачимо, що в останні роки зростає кількість молоді із захворюванням серцево-судинної, дихальної та нервової систем. Значні показники мають такі хвороби, як алкоголізм, тютюнопаління й наркотична залежність. В останні роки лише піднімаються заклики бути здоровим, а реальні дані свідчать про систематичне погіршення здоров'я учнівської молоді 3 кожним роком. Однією $з$ причин такого стану є зниження інтересу широких верств населення до організованих і самостійних систематичних занять фізичним вправами, недостатня виховна та освітня спрямованість діяльності учителів фізичної культури на уроках і в позаурочний час.

Пошуки оптимальних шляхів залучення підростаючого покоління до фізичної культури випливають з основ перебудови національної школи, де значне місце відведено фізичному розвитку, загартуванню, а фізична культура й спорт мають стати повсякденною потребою їхнього життя [9].

Це положення конкретизує Закон України «Про фізичну культуру і спорт», у якому підкреслено, що фізична культура $\epsilon$ складовою частиною загальної культури суспільства, спрямованої на зміцнення здоров’я, розвиток фізичних, морально-вольових та інтелектуальних здібностей людини задля підвищення гармонійного формування ii як особистості.

Фізична культура - це важливий засіб підвищення соціальної й трудової активності людей, задоволення їхніх моральних, естетичних та творчих запитів, життєво важливої потреби взаємного 
спілкування, а спорт є органічною частиною фізичної культури, особливою сферою виявлення й уніфікованого порівняння досягнень людей у певних видах фізичних вправ, технічної, інтелектуальної та іншої підготовки шляхом змагальної діяльності [2].

На відміну від охорони здоров'я, фізична культура не має чітко визначеної сфери дії, вона призначена для всебічного розвитку людського тіла й духу та, кажучи спрощено, якщо охорона здоров'я бореться з наслідками негативних процесів, то фізична культура попереджає її, допомагає їх уникнути.

У своїй основі фізична культура, як і кожна з видів культури, має духовно-матеріальну форму вираження, ii духовна сторона проявляється в зростанні загального інтелекту людини, у зміні іiі психоемоційного стану, розумових здібностей, у надбанні науково-теоретичних знань із галузі фізичної культури, спорту, інших гуманітарних та біологічних наук (психології, педагогіки, соціальної психології, анатомії, фізіології, гігієни, біомеханіки) і їх раціональне застосування в повсякденному житті.

Отже, основними завданнями фізичної культури є:

- підвищення функціональних можливостей організму людини засобами фізичної культури;

- сприяння всебічному гармонійному розвитку;

- відмова від шкідливих звичок, покращення розумової й фізичної працездатності;

- формування в молоді позитивного ставлення до систематичних занять фізичними вправами 3 урахуванням особливостей їхньої майбутньої професії;

- фізичне самовдосконалення та здоровий спосіб життя;

- використання засобів фізичної культури в лікувально-профілактичній діяльності;

- оволодіння методами визначення фізичного стану й самоконтролю; виховання організаторських навиків, особистої гігієни та загартовування організму;

- уміння складати й виконувати вправи з комплексів ранкової гігієнічної гімнастики;

- виховання патріотичних, морально-вольових та естетичних якостей. Держава законодавчо захищає інтереси громадян у сфері фізичної культури й спорту, розвиває фізкультурно-спортивну індустрію та інфраструктуру, заохочує прагнення молоді зміцнювати своє здоров'я, вести здоровий спосіб життя.

У зв'язку з цим виникає необхідність пошуку нових форм і підходів до організації позанавчальної фізкультуро-оздоровчої та спортивно-масової роботи з молоддю, які б відповідали сучасним соціально-економічним реаліям. Упровадження ефективних форм, методів і засобів фізкультурноспортивної діяльності й видів спорту з урахуванням місцевих і регіональних особливостей, традицій, економічних факторів, умов праці та вільного часу населення.

Потрібно відзначити поширення в Україні міжнародного руху «Спорт для всіх», який розглядає фізкультурні заняття як невід’ємне право кожного громадянина, незалежно від етнічних, вікових, статевих відмінностей, соціального статусу й можливостей. Це нове досягнення світового суспільства, яке має прихильників у багатьох країнах, спрямоване на зміцнення здоров'я та розвиток фізичної підготовленості населення за допомогою спортивних і рекреаційних видів оздоровчої рухової активності.

Постановою Кабінету Міністрів України від 18 січня 2003 р. № 49 у країні розпочалося створення Всеукраїнського, обласних, районних і міських центрів фізичного здоров'я населення «Спорт для всіх» [7].

Для активізації руху «Спорт для всіх» потрібно виконати державними й громадськими організаціями низку практичних заходів. Насамперед треба активізувати фізкультурно-оздоровчу діяльність різних верств населення за місцем проживання [6]. Спортивні школи, спортивні й оздоровчі клуби, фітнес-центри, які функціонують нині, повинні стати передовою ланкою у виконанні поставлених завдань сучасного суспільства.

Ринок фітнес-індустрії України переживає період розвитку. За даними дослідження Fitness Connect UA в Україні станом на кінець 2017 р. ідентифіковано 1569 фітнес-об’ єктів (фітнес-клуб - це об’єкт фітнес-індустрії, який призначений для надання фітнес-послуг на комерційній основі 3 можливістю придбання абонемента (разового, місячного, річного), основна частина 3 котрих припадає на фітнес-клуби [10].

Як показало дослідження, в Україні фітнес-послугами охоплені переважно обласні центри й великі міста, у той час як фітнес-об'єктів майже немає в районах і взагалі немає, за деякими винят- 
ками, у маленьких містечках та сільській місцевості [5]. Так, на сьогодні в Україні набувають розвитку фітнес-студії, жіночі фітнес-клуби та кросфітклуби. Основна частина об'єктів (60\%) зосереджена у великих містах України, уключаючи м. Київ, а на м. Чернівці припадає всього 2 \% фітнесоб'єктів від загальної кількості (для аналізу обрано клуби, дані про які наявні для відкритого доступу).

Проаналізувавши статистичні звіти про наявність спортивних клубів за 2002-2003 рр. в Україні, зазначимо, що у всіх областях, крім Чернівецької, діяли спортивні клуби [8].

Розглянувши звітну інформацію з питань фізичної культури та спорту в Чернівецької області за 2018 р., ми відзначаємо, що на території Чернівецької області працює 11 центрів фізичного здоров'я населення «Спорт для всіх», серед них - один регіональний центр, три районні, шість міських та один селищний центр. За минулий рік центрами ФЗН «Спорт для всіх» проведено 198 масових заходів, у яких узяли учать понад 9 тис. буковинців. В області проведено сім галузевих спартакіад [3].

Також зазначимо, що за досліджуваний період у Чернівецької області відкрилися 12 спортивних клубів із літніх олімпійських видів: із баскетболу, бейсболу, боксу, боротьби вільної, волейболу, дзюдо, карате, плавання, скелелазіння, тенісу, фехтування та футболу.

А 3 неолімпійських видів спорту працюють 25 спортивних клубів: авіамодельний, автомобільний, автомодельний, армспорту, більярдного спорту, бодібілдингу, дартсу, змішаних єдиноборств (MMA), городкового спорту, карате WKC, кікбоксингу ICKA, кікбоксингу WAKO, козацьких боїв, мотоциклетного спорту, панкратіону, пауерліфтингу, пожежно-прикладного спорту, радіоспорту, спорту із собаками, спортивного туризму, спортивних танців, фітнесу, чарлідингу, кросфіту, оздоровчої ходьби [3].

Дискусія. Результати проведеного дослідження дали підставу доповнити вже відомі наукові розробки з цієї тематики, а також отримати нові дані в аспекті проблеми, що вивчалася. Так, у результаті дослідження підтверджено результати вивчення (Імас С., 2015) щодо тенденції розвитку сфери фізичної культури й спорту в умовах сучасного ринку; результати досліджень (Кононович В. Г., 2012) стосовно державного регулювання сфери фізкультурно-спортивних послуг. Узагальнюючи результати проведеного дослідження, можемо констатувати, що в нашому дослідженні набули подальшого розвитку наукові знання (Нікітенко С. В., 2016) щодо ефективного державного управління фізичною культурою й спортом в Україні.

Висновки. На сьогодні існує потреба в проведенні якісних змін у сфері фізичної культури та спорту на основі використання сучасних підходів в організації й діяльності різноманітних фітнес центрів і клубів.

Особливої актуальності набуває розвиток фітнес послуг на основі збільшення кількості спортивних клубів та фітнес-об'єктів різних форм власності.

Тому завданням і української влади, і представників фітнес-індустрії є потреба зробити все можливе для того, аби фітнес та здоровий спосіб життя, загалом, стали доступними не лише для певних категорій населення, а й будь-якої людини, незалежно від місця ії̈ проживання.

Сучасні оздоровчі клуби й фітнес-центри надають переважно платні послуги бажаючим і $є$ доступними не для всіх верств населення. Поєднання спеціально організованих та самостійних видів оздоровчої рухової активності в діяльності центів фізичного здоров'я населення «Спорт для всіх» $\epsilon$ актуальним на цьому етапі розвитку індустрії спорту.

Задля втілення цієї мети, що зробить більш здоровою всю українську націю, потрібно всебічно сприяти розвитку фітнес-індустрії, аби найближчі кілька років збільшити кількість тих, хто займається фітнесом у нашій країні.

\section{Джерела та література}

1. Дутчак М. В. Спорт для всіх в Україні: теорія і практика. Київ: Олімп. літ., 2009. 279 с.: ілюстр.

2. Закон України про фізичну культуру та спорт. URL: https://zakon.rada.gov.ua/laws/show/3808-12\#Text

3. Звіт «Про підсумки роботи управління молоді та спорту обласної державної адміністрації за 2018 p. URL: https://bukoda.gov.ua/page/group/155

4. Імас С., Мічуда Ю. Тенденції розвитку сфери фізичної культури та спорту в умовах сучасного ринку. Теорія і методика фізичного виховання і спорту. 2015. № 2. С. 142-149.

5. Кононович В. Г. Державне регулювання сфери фізкультурно-спортивних послуг. Державне будівниџтво. 2012. № 2. URL: http://nbuv.gov.ua/UJRN/DeBu_2012_2_51

6. Нікітенко С. В. Ефективність державного управління фізичною культурою та спортом в Україні. Актуальні проблеми державного управління. 2016. № 1. С. 49-54. 
7. Постанова кабінету Міністрів України про створення центрів фізичного здоров’я населення «Спорт для всіх» від 18.01. 2003 р. № 49 м. Київ.

8. Україна спортивна в цифрах та коментарях/Дані звіту Державного комітету з питань фізичної культури і спорту за 2004 р. Київ, С. 6-43.

9. Сухенко I. Формування культури здоров'я - необхідний компонент виховання молоді. Фізичне виховання, спорт і культура здоров'я у сучасному суспільстві. 2019. 1 (45). 29-36. URL: https://doi.org/ 10.29038/2220-7481-2019-01-29-36

10. URL: https://fitnesscjnnekt.com.ua

\section{References}

1. Dutchak, M. V. (2009). Sport dlia vsikh v Ukraini: teoriia i praktyka. Kyiv: Olimpiiska lit., 279 p.: il.

2. Zakon Ukrainy pro fizychnu kulturu ta sport. URL: https://zakon.rada.gov.ua/laws/show/3808-12\#Text

3. Zvit «Pro pidsumky roboty upravlinnia molodi ta sportu oblasnoi derzhavnoi administratsii za 2018 r. URL: https://bukoda.gov.ua/page/group/155

4. Imas, Ye., Michuda, Yu. (2015). Tendentsii rozvytku sfery fizychnoi kultury ta sportu v umovakh suchasnoho rynku. Teoriia i metodyka fizychnoho vykhovannia i sportu, 2, 142-149.

5. Kononovych, V. H. (2012). Derzhavne rehuliuvannia sfery fizkulturno-sportyvnykh posluh. Derzhavne budivnytstvo, 2. URL: http://nbuv.gov.ua/UJRN/DeBu_2012_2_51

6. Nikitenko, S. V. (2016). Efektyvnist derzhavnoho upravlinnia fizychnoiu kulturoiu ta sportom v Ukraini. Aktualni problemy derzhavnoho upravlinnia, 1, 49-54.

7. Postanova kabinetu Ministriv Ukrainy pro stvorennia tsentriv fizychnoho zdorovia naselennia «Sport dlia vsikh» vid 18.01. 2003 r., № 49, m. Kyiv.

8. Ukraina sportyvna v tsyfrakh ta komentariakh / Dani zvitu Derzhavnoho komitetu z pytan fizychnoi kultury i sportu za 2004 r. Kyiv, 6-43.

9. Sukhenko, I. (2019). Formuvannia kultury zdorov'ia - neobkhidnyi komponent vykhovannia molodi. Fizychne vykhovannia, sport i kultura zdorovia u suchasnomu suspilstvi, 1 (45), 29-36.

10. URL: https://fitnesscjnnekt.com.ua

Стаття надійшла до редакції 12.03.2020 p. 